helpmeet, two step-daughters, of whom the elder is the wife of his pupil and successor in the Professorship, the eminent scholar and explorer, Dr. Georg Morgenstierne. Prior to the heavy blow of his wife's death in 1931, but also afterwards, he delighted to receive the visits of scholar friends in his Oslo residence or in his retreat on the Christiania Fiord or later in his tiny island off the coast.

F. W. Thомаs.

\title{
Mr. C. E. A. W. Oldham, C.S.I., F.R.G.S.
}

By the death of Mr. C. E. A. W. Oldham, in November, at the age of 80 , at his residence in Kensington, the Society has lost a valued member, who for years past took an active part in its affairs. Mr. Oldham joined it in 1924, and, after serving as a Member of the Council, became Honorary Secretary from 1935 to 1941, after which he was elected as an Honorary Vice-President, which he continued to be until his death. He was always ready to advise on the Indian Section of the Journal, and until recently was a constant reviewer.

Charles Evelyn Arbuthnot William Oldham was educated at Galway Grammar School and Balliol College, Oxford. He passed into the Indian Civil Service in 1885 and, after being engaged in Secretariat and District work in Bengal, became Director of Agriculture in 1906, Secretary to the Government in the Financial and Municipal Department in 1908, and then Commissioner of Excise. When the Province of Bihar and Orissa was created, in 1911, he was transferred to that Province, where he had served as a District Officer, and there completed his service as Commissioner of the Patna Division and, finally, as Member of the Board of Revenue. He retired in 1919. Oldham received the Kaisar-i-Hind gold medal for work in the famine in 1902, and the C.S.I. in 1918.

Throughout his service he took a keen interest in the language and customs of the people of Bihar, and in archæology, and, especially in the Magadhi, Maithili, and Bhojpuri varieties of the Bihari language spoken in districts, which he knew intimately. He compiled an exhaustive list of proverbs in those languages, though he did not publish it.

After retirement Oldham was for several years Assistant Editor of the Indian Antiquary, of which the second Sir Richard Temple was then editor ; on Sir Richard's death, in 1931, he became the Editor, until, for financial reasons, publication ceased in 1934. He also edited, 
with Introduction and Notes, The Journal of Francis Buchanan, relating to certain of the Bihar Districts.

He had a keen intellect and extensive knowledge, and was of a most generous nature, and always ready to impart his knowledge. His death is a great loss to a large number of friends, by whom he will be affectionately remembered.

8th December, 1949.

E. H. C. WALSh. 